\title{
GENETIC EVALUATION FOR MILK PRODUCTION, REPRODUCTION AND SOMATIC CELL COUNT TRAITS IN EARLY LACTATION FOR FRIESIAN CATTLE IN EGYPT Shalaby, N.A. 1; M. A. Mostafa ${ }^{1}$; M. F. Abdel-Glil ${ }^{2}$ and M. A. Z. Alemam ${ }^{1}$ \\ 1- Department of Animal production, Fac. of Agric., Mansoura University 2- Animal production Research Institute. Ministry of Agriculture. Dokki, Cairo, Egypt.
}

\begin{abstract}
A total of 2396 records of 673 Holstein Friesian cows were collected from one commercial Holstein Friesian farm during the period from 1999 to 2004. Genetic, phenotypic correlations and breeding values for productive, reproductive and somatic cell count traits were analyzed by using single-trait and multi-trait animal model analyses. Traits studied were total milk yield (TMY, kg), days in milking (DIM, days), milk yield in first test of lactation after calving (M1, kg), days open (DO, days), number services per conception (NSC, services), age at first calving (AFC, month), and somatic cell count in the first test of lactation (SCC).

Unadjusted means of TMY, M1, DIM , SCC1, AFC, NSC and DO were 6716 $\mathrm{kg}, 17.39 \mathrm{~kg}, 319.8$ day, $505.23 \times 103 \mathrm{cell} / \mathrm{ml}, 28.3$ month, 1.97 services and 144.5 day, respectively. Estimates of heritability of TMY, DIM, M1, SCC1, AFC, NSC and DO were $0.34 \pm 0.028,0.22 \pm 0.08,0.10 \pm 0.026,0.04 \pm 0.023,0.20 \pm 0.113,0.02 \pm 0.013$ and $0.02 \pm 0.017$ for single-trait, While, the obtained $\mathrm{h}^{2}$ from multi-trait analysis were $0.40 \pm 0.12,0.20 \pm 0.16,0.16 \pm 0.02$ and $0.10 \pm 0.08$ for TMY, M1, DO and SCC1, respectively. The genetic correlations among TMY, M1, SCC1 and DO were positive and ranged from $0.19 \pm 0.06$ to $0.84 \pm 0.08$. The phenotypic correlations between milk production and reproduction traits were positive for all studied traits and ranged between 0.10 for correlation between SCC1 and TMY to 0.44 for correlation between M1 and DO.

The range of breeding values obtained from single-trait analysis for DO, TMY, M1, SCC1 and AFC were 20.9 day, $6006 \mathrm{~kg}, 229 \mathrm{~kg}, 57.7 \times 10^{3} \mathrm{cell} / \mathrm{ml}$ and 3.83 month, respectively. While, the breeding values obtained from multi-trait analysis for all animals were 193.9 day, $10280 \mathrm{~kg}, 383.8$, and $630 \times 10^{3}$ cells $/ \mathrm{ml}$ for DO, TMY, M1, and SCC1, respectively. The present results will help the farmers to select the best dairy cows based on a combination of production, reproduction and somatic cell count in early lactation.
\end{abstract}

\section{INTRODUCTION}

Mastitis is one of the most common dairy cow diseases. Therefore, it can cause considerable economic losses to dairy farmers, which are caused by ways factors, such as decreasing milk yield, marked compositional changes in milk lead to reduce milk quality, increasing labor costs, and increasing risk of early culling of cows. Hagnestam et al. (2007) estimated a reduction in 305-day milk production between $0.0-902 \mathrm{~kg}(11 \%)$ depending on parity and the week time of lactation at clinical onset (Veerkamp et al., 1998). Somatic cell count in milk (mainly the number of white blood cells) is the most common way of measuring milk quality as well as udder health 
Shalaby, N.A. et al.

(Harmon, 1994). Itavo et al., (2001) found that mastitis has been the disease that causes the high costs in the milk production resulting in significant losses. Tsenkova et al. (2001) reported that somatic cell count is recognized as a good indicator of cows' health and milk quality. Also, somatic cell count reflects the level of infection and resultant inflammation in the mammary gland of dairy cows associated with mastitis.

Detilleux et al. (1997) suggested that the risk of intramammary infection from environmental pathogens, which lead to a brief increase in SCC, is high at the beginning of lactation when cows are metabolically stressed. Li et al. (2001) concluded that, in spite of such brief or short elevations in SCC observed in early lactation had very low heritability, they are highly genetically correlated (0.90-0.95) with overall lactation somatic cell score. Therefore, it is important to consider mastitis in dairy cattle breeding (Koivula et al., 2005). So, the main objectives of the present study were: 1) To evaluate the productive, reproductive traits and somatic cell count of Holstein Friesian cows under commercial herd in Egypt, 2) to estimate heritability, genetic and phenotypic correlations among production, reproduction traits and somatic cell count by using single and multi-traits animal model, 3) to estimate breeding values for these traits which obtained from single and multi-traits and 4) to estimate the correlations between breeding values for all traits.

\section{MATERIALS AND METHODS}

Data on milk production, reproduction traits and somatic cell count were collected from one commercial Holstein Friesian herd. The herd is situated in the northern part of Delta, south Domiate government. Total of 2396 records of 673 (sired by 68 sire) Holstein Friesian cows in the first five parities were collected during the period from 1999 to 2004.

The animals were housed free in open yards, and the cows were fed on Egyptian clover (Trifolium Alexandrinum), rice straw and Sorghum as silage, in addition to concentrate mixture in winter according to their milk yield level.

In summer and autumn, the animals were fed on concentrate mixture , rice straw, clover hay and Sorghum as green fodder. Water was offered freely. Cows were machine milked three time daily at 4.00 a.m., 12.00 a.m. and 8.00 p.m. After calving, calves were suckled colostrums' from their dams for three days after then they were separated. The cows were dried when the daily milk production was reduced to less than $2 \mathrm{~kg}$ and/or at two months before the next calving. Cows were artificial insemination. Pregnancy diagnosis via rectal palpation was performed on day 60 after the last service. Traits studied were total milk yield (TMY), milk yield in the first test of lactation (M1), days in milking (DIM), somatic cell count in first test of lactation (SCC1), age at first calving (AFC), number of services per conception (NSC) and days open (DO).

Animal models were used for analyses for all data. The multiple-trait derivative-free restricted maximum likelihood (MTDFREML) suite of programs (Boldman et al. 1995) was used for univariate and multiple-trait analyses for 
all traits. Effects of year and month of calving and parity were assumed to be fixed. Days open and age at first calving (AFC) were included in the model as covariate when total milk yield and days in milk were analyzed. Milk yield and AFC were included in the model as covariate when reproduction traits were analyzed, Days from parturition to the fist test and AFC were included in the model as covariate when test day of milk yield and somatic cell count were analyzed and effects of animal, direct and permanent environmental effect and random residual effect considered to be random. In multiple traits general animal model used was:

Where:

$$
Y=X \beta+Z a+W p e+e
$$

$Y=$ observations vector of records, $\beta=$ the vector of fixed effects, $p e=$ the vector of environmental effects contributed by dams to records of their progeny (permanent environmental), and $\mathrm{e}=$ the vector of residual effects. $\mathrm{X}$, $\mathrm{Z}$ and $\mathrm{W}$ are incidence matrices relating records to fixed, direct genetic and permanent environmental effects, respectively.

Mixed-model equations in the analyses were solved iteratively. Based on the variance of the log-likelihood function values, the convergence criterion was $1 \times 10^{-9}$. In addition, several restarts were necessary until changes in the log-likelihood function values were less than $1 \times 10^{-5}$. Restarts were performed for all analyses, using the final results of the previous analysis, in order to locate the global maximum for the log likelihoods. Starting values for variance components for multi-trait analyses were obtained from single-trait analyses on individual traits. Best linear unbiased prediction (BLUP) of estimated breeding values (EBVs) were obtained by back-solution using the MTDFREML program for all animals in the pedigree file for single-trait and two-trait analysis with milk yield. Additionally, Spearman rank correlations between EBVs for traits were studied from single-trait and multi-trait analyses.

\section{RESULTS AND DISCUSSIONS}

Unadjusted means, standard deviations (S.D) and coefficients of variation (C.V\%) of productive traits of Holstein Friesian cows are shown in table (1). The overall unadjusted mean of TMY $(6716 \pm 2355 \mathrm{~kg})$ was nearly similar to that reported by Shalaby (2005) being $6733 \mathrm{~kg}$ using Friesian cows in Egypt. While, higher than those reported by Hegazy and Morsy (2005) being 2837, 2572, and $2780 \mathrm{~kg}$ for $1^{\text {st }}, 2^{\text {nd }}$, and $3^{\text {rd }}$ lactations; Tag-El-Dein and Hussein (2005) being $4857 \mathrm{~kg}$. Coefficient of variation (CV\%) was $35.07 \%$ for TMY higher than those reported by Aboul-Ela et al. (2001) being in the first three lactations were $24.1,25.9$, and $25.8 \%$, respectively. Also, higher than those by Alemam (2002) being 26.7. The overall unadjusted mean of DIM (319.8 \pm 128.0 days) was considerably lower than that reported by Shalaby (2005) showed that unadjusted mean of DIM was 353.9 days for using Friesian cows in commercial herds in Egypt.

Coefficient of variation (CV\%) was $40.02 \%$ for days in milk. The present result was higher than those reported by Alemam (2002) being 
Shalaby, N.A. et al.

$24.7 \%$. The overall unadjusted mean of milk yield in the first test after calving was $17.39 \pm 8.10 \mathrm{~kg}$. Coefficient of variation (CV\%) was $46.6 \%$ for milk yield in the first test lactation after calving.

The overall unadjusted means, standard deviations (S.D) and coefficients of variation of reproductive traits of Holstein Friesian cows are shown in table (1). The overall unadjusted mean of NSC $(1.97 \pm 1.38$ services). These value was nearly similar to that reported by Alemam (2002) being 1.96 services. Coefficient of variation (CV\%) of NSC $(70.05 \%)$ was considerably higher than reported by Oudah et al (2001) being $61.0 \%$. While, lower than those reported by Alemam (2002) being 94.59\%.

Table (1): Unadjusted means $\left({ }^{x}\right)$, standard deviations S.D, and coefficients of variation C.V\% for studied traits.

\begin{tabular}{|l|c|c|c|c|}
\hline \multicolumn{1}{|c|}{ Traits } & Abbre. & $\bar{x}$ & S.D & C.V\% \\
\hline Total milk yield, Kg & TMY & 6716 & 2355 & 35.07 \\
Milk yield in the first test of lactation, Kg & M1 & 17.39 & 8.10 & 46.6 \\
Days in milking, Days & DIM & 319.8 & 128.0 & 40.02 \\
Somatic cell count in first test of lactation, $10^{3}$ cell & SCC1 & 505.23 & 1059 & 209.6 \\
Age at first calving, Month & AFC & 28.03 & 3.29 & 11.74 \\
Number of services per conception, service & NSC & 1.97 & 1.38 & 70.05 \\
Days open, Days & DO & 144.5 & 81.5 & 56.40 \\
\hline
\end{tabular}

Unadjusted mean of DO was $144.5 \pm 81.5$ days, these value was higher than reported by Alemam (2002) being 140.43 days. While, lower than reported by Shalaby (2005) being 162.7 day in dairy commercial Holstein Friesian herds. Coefficient of variation (CV\%) was $56.45 \%$ for DO. These nearly similar to Oudah et al (2001) being 56.9.

The overall unadjusted mean of AFC was $28.03 \pm 3.29$ month. This value was nearly similar to Atil and Khattab (2005a) being 28.8 month and higher than Shalaby (2005) being 27.7 months. While, lower than Ashmawy (1986) being 32 month. A reduction in age at first calving can be achieved through better feeding, management, disease control and efficient heat detection and timely service programmed. Coefficient of variation (CV\%) of AFC was $11.74 \%$.

Unadjusted mean of somatic cell count was $505.23 \times 10^{3} \mathrm{cell} / \mathrm{ml}$. This value was higher than reported by O'Rourke (1999). Also, Itavo et al., (2001) showed that the somatic cell count level considered normal is less than 200,000 cells $/ \mathrm{ml}$ of milk, although it may be less in the first lactation. Dohoo and Meek, (1982) showed that in dairy cattle both 400000 and 500000 cells $/ \mathrm{ml}$ have been evaluated as possible thresholds, for classifying a quarter as being infected, but both will resulted in a high false negative rate. Coefficient of variation (CV\%) of somatic cell count in milk was $209.6 \%$ for somatic cell count in milk. The large coefficients of variation are lead to opportunities for improvement in these traits. Holsteins in commercial herds in Egypt are showing high production performance under adequate management. 
Heritability

Heritability estimates and their standard errors of milk production, reproduction traits and somatic cell count obtained from single-and multi-traits genetic analysis are shown in tables 2 and 3 . Single-trait analysis of data gave an estimate of $0.34 \pm 0.028$ for the heritability of TMY and also by multitraits analyses gave an estimate of $0.40 \pm 0.12$. The heritability estimated of TMY in this study fall within the range of the available heritability estimates obtained in the literature. As that reported by Shalaby (2005) for heritability of 305 days-milk yield and TMY were $0.34 \pm 0.107$ and $0.28 \pm 0.139$ using singletrait analysis for Holstein Friesian cows, Tag El-Dein (1997) being 0.38. ElAwady (1998) using Friesian cows of total milk yield was 0.43 . While, it was higher than that reported by Alemam (2002) for total milk yield was 0.184 .

It could be noticed that value of heritability of DIM for single-trait was $0.22 \pm 0.08$ (table 2). Abdel-Glil (1996) recorded nearly similar $\mathrm{h}^{2}$ of 0.27 for DIM and Shalaby (2005) being $0.27 \pm 0.091$ using single-trait analysis for Holstein Friesian cows. The present result was higher than that reported by El-Awady (1998) being (0.14), Farrag et al. (2000) being 0.05, and Alemam (2002) being 0.062 . But, it was lower than that reported by Tag El-Dein (1997) $\mathrm{h}^{2}$ of DIM was 0.37 .

Single-trait analysis gave an estimate of $0.10 \pm 0.026$ and also, multitraits analyses gave an estimate of $0.20 \pm 0.16$ for the heritability of M1. Nearly similar findings was reported by Reents et al. (1995) that heritability estimates of SCS were from 0.10 in the first lactation to 0.13 in the third lactation. While, Amin et al. (2005) stated that heritability estimates for SCS did not showed clear trend of month of lactation with estimate 0.09 from zero day to three lactation months. In the other side, Mrode and Swanson (2001) reported that $\mathrm{h}^{2}$ of SCS increased slightly with days in milk in all parities.

Table (2): Heritability estimates $\left(h^{2}\right)$ and standard errors (S.E ) for single-traits.

\begin{tabular}{|l|c|c|}
\hline \multicolumn{1}{|c|}{ Traits } & $\mathbf{h}^{2}$ & S.E \\
\hline TMY & 0.34 & 0.028 \\
M1 & 0.10 & 0.026 \\
DIM & 0.22 & 0.08 \\
SCC1 & 0.04 & 0.023 \\
AFC & 0.20 & 0.113 \\
NSC & 0.02 & 0.013 \\
DO & 0.02 & 0.017 \\
\hline
\end{tabular}

It could be noticed that value of heritability of days open for singletrait was $0.02 \pm 0.017$, and the value was $0.16 \pm 0.02$ using multi-traits. These results was nearly similar to that reported by Moore et al. (1999) being heritability ranged from 0.03 to 0.06 . Also, Abdel-Glil (1996) recorded 0.12 , Pryce et al. (1998) obtained 0.017 and 0.005 for the $1^{\text {st }}$ and $2^{\text {nd }}$ lactation, Oudah et al. (2001) being 0.105 \pm 0.038 and Alemam (2002) being $0.176 \pm 0.05$. similarly, Shalaby (2005) reported estimate of heritability of DO was $0.11 \pm 0.064$ using single-trait. 
Shalaby, N.A. et al.

Single-trait analysis gave an estimate of $0.02 \pm 0.013$ for the heritability of NSC. The obtained present value fall within the range of the heritability of the available estimates reported in the literature. In this trend, Alemam (2002) recorded 0.036 and Estrada-Leon et al. (2008) obtained 0.04. The low estimates for above reproductive traits indicated that environmental effects are more important than additive genetic effect.

Single-trait analysis gave an estimate of $0.20 \pm 0.113$ for the heritability of AFC. Similar estimate reported by Estrada-Leon et al. (2008) being 0.28 on Brown Swiss cows. While, it was lower 0.36 than that reported by Toosi (2002) on Holstein cattle.

The results in the present study indicated to the differences in heritabilities obtained from single versus two-trait genetic analyses (Table 2 and 3). In this respect, Schaeffer (1984) compared accuracies of single- and multiple-trait analyses of milk and fat yields, he concluded that genetic and residual correlations between traits affect the choice of analysis and are more important than the number of animals. Moreover, multi-trait analysis of fertility with milk yield as an additional trait is a different approach which aims to improve accuracy of genetic evaluations for the traits involved by reducing variances of prediction error of estimated breeding values (Schaeffer, 1984). The value of $h^{2}$ from multi trait analysis reported in the present study indicated that the improvement of studied traits could be achieved through better management besides genetic selection.

\section{Genetic and phenotypic correlations}

Estimates of genetic correlations among TMY, M1, DO and SCC1 are shown in table (3). The genetic correlation between TMY and M1 were positive being $0.27 \pm 0.15$.however, El-Awady (1998) recorded 0.81 and Shalaby (2005) obtained positive and high (0.85) in their studied on Holstein Friesian cows in Egypt. The high and positive genetic correlation between TMY, DIM and M1 indicated that selection for one trait would be associate with genetic improvement in the other.

It could be noticed that these correlations were positive and ranged from $0.19 \pm 0.06$ for correlation between M1 and SCC1 to $0.84 \pm 0.08$ between M1 and DO. In this trend, Shalaby (2005) obtained higher estimate (0.82) for genetic correlation between TMY and DO.

Table (3): Estimates of heritability $\left(h^{2}\right)$ and standard errors (S.E) (diagonal), phenotypic correlations (above), and genetic correlations \pm S.E (below) among the traits.

\begin{tabular}{|lcccc|}
\hline Traits & TMY & M1 & DO & SCC1 \\
\hline TMY & $\mathbf{0 . 4 0 \pm 0 . 1 2}$ & 0.19 & 0.40 & 0.10 \\
M1 & $0.27 \pm 0.15$ & $\mathbf{0 . 2 0 \pm 0 . 1 6}$ & 0.44 & 0.177 \\
DO & $0.46 \pm 0.13$ & $0.84 \pm 0.08$ & $\mathbf{0 . 1 6} \pm 0.02$ & 0.175 \\
SCC1 & $0.30 \pm 0.13$ & $0.19 \pm 0.06$ & $0.35 \pm 0.10$ & $\mathbf{0 . 1 0 \pm 0 . 0 8}$ \\
\hline
\end{tabular}

Estimates of genetic correlation between somatic cell count and milk yield in the first test was positive $0.19 \pm 0.06$ The obtained result was nearly similar with Rupp and Boichard (1999) that estimates of genetic correlation between yields and SCC were moderately unfavorable (from 0.11 to 0.27 ). In the same Monardes and Hayes (1985) found that the genetic correlations for 
SCC between adjacent lactations vary considerably, from 0.44 to near unity; they added that genetic correlations tend to be lower as distance between lactations increases. In the other direction, Koivula et al., (2005) showed that the genetic correlation between SCC and milk yield was positive in the first lactation, but negative or near zero in the second lactation. Estimate of genetic correlation between SCC and DO was positive and moderate being $0.35 \pm 0.10$ ( Table 3).

The phenotypic correlations among TMY, M1, DO and SCC1 were positive and ranged from 0.10 for correlation between SCC1 and TMY to 0.44 for correlation between $\mathrm{M} 1$ and $\mathrm{DO}$.

The phenotypic correlations between reproductive trait (DO) and milk production traits (TMY and M1) were positive ( 0.40 and 0.44 , respectively) In this respect, Aboul-Ela et al. (2000) recorded 0.52 between production and reproduction traits in their study on Friesian cows, and Oudah et al. (2001) found 0.50 for Friesian cows. Also, Shalaby (2005) reported that the phenotypic correlation between DO and TMY was 0.49 . These estimates indicated that higher-yielding animals were associated with undesirable longer DO. The effect of high milk production on the incidence of reproductive disorders may be related to the degree to which energy balance becomes negative in the early postpartum period. During early lactation, many high producing cows are unable to consume enough feed to meet their energy demands, which could result in reduced reproductive performance (Gröhn et al., 1994).

\section{Breeding values}

Means, maximum, minimum, standard deviations, and range of estimated breeding values (EBV) of productive, reproductive and somatic cell count traits in all pedigree and for all animal obtained from single-traits analysis are presented in Table 4 . Regarding the breeding values obtained from single-trait analysis, the range of all pedigree animals for DO, TMY, M1, SCC1 and AFC were 20.9 day, $6006 \mathrm{~kg}, 229 \mathrm{~kg}, 57.7 \times 10^{3} \mathrm{cell} / \mathrm{ml}$ and 3.83 month, respectively. While, the range of breeding value of DO, TMY, M1, and SCC1 of multi-trait were 193.9 day, $10280 \mathrm{~kg}, 383.8$ and $630 \times 10^{3} \mathrm{cells} / \mathrm{ml}$ for all animals (Table 5). The present results indicate that the wide range of breeding values for all reproductive traits, suggests the existence of genetic variation between animal and hence the possibility of sire selection for daughter's productive traits by using multi- trait reproductive in the next generation is a goal of dairymen. In this respect Shalaby (2005) showed that the range of breeding value obtained from single-trait analysis for all pedigree animals for AFC, DO, 305-d MY, DIM and 70-d MY were 5.2 months, 99.71 days, $3917 \mathrm{~kg}, 176.4$ days and $1039.1 \mathrm{~kg}$, respectively, while the range of sire breeding value were 4.86 months, 61.59 days, $2938 \mathrm{~kg}, 142.82$ days and $902 \mathrm{~kg}$, respectively. Also, Atil and Khattab (2005b) reported that the range of sire breeding values were $388 \mathrm{~kg}$ and 4.64 days for 305-d MY and DIM, respectively. The same authors found that the rang of sire breeding value for 305-d MY was $2186 \mathrm{~kg}$ of Holstein Friesian cattle in Turkey. Atil and Khattab (2005a) found that the range of sire breeding value for AFC was14.31 months. 
Shalaby, N.A. et al.

Table (4): Means, maximum, minimum, standard deviations, and range of estimated breeding values (EBV) of productive, reproductive and somatic cell count traits for all animals obtained form single-traits analysis.

\begin{tabular}{|l|c|c|c|c|c|c|c|c|c|c|}
\hline \multicolumn{10}{|c|}{ Single-trait breeding value } \\
\hline TRAITS & \multicolumn{2}{|c}{ DO } & \multicolumn{2}{c|}{ TMY } & \multicolumn{2}{c|}{ M1 } & \multicolumn{2}{c|}{ SCC1 } & \multicolumn{2}{c|}{ AFC } \\
\hline & EBV & S.E & EBV & S.E & EBV & S.E & EBV & S.E & EBV & S.E \\
\hline Means & 0.036 & 10.1 & 25.20 & 1026 & 45.12 & 6.33 & 13.13 & 20.2 & -0.033 & 1.01 \\
Max & 11.4 & 10.5 & 3174 & 1360 & 116.5 & 705 & 34.05 & 21.80 & 1.825 & -0.014 \\
Min & -9.4 & 7.6 & -2832 & 450 & -102.4 & 344 & -14.66 & 13.80 & -2.01 & 0.59 \\
S.D & 24.3 & 0.34 & 773.9 & 216.5 & 291.8 & 54.22 & 47.48 & 9.97 & 0.436 & 0.0758 \\
Range & 20.9 & 18.1 & 6006 & 1810 & 229.3 & 104.9 & 57.71 & 35.60 & 3.834 & 0.604 \\
\hline
\end{tabular}

The present results showed higher estimates of standard deviations for multi-trait than single-trait analyses. The differences in distribution (S.D) of breeding values between single-trait versus multi-trait analyses may be due to high absolute differences between genetic and phenotypic correlations between milk yield, reproduction and somatic cell count traits. Higher standard deviations of breeding value for multi-trait than single-trait analyses obtained in the present study indicated the existence of more genetic variation among animals and hence increases the possibility of sire selection for the traits studies. Kadarmideen et al. (2003) reported similar results.

Table (5): Means, maximum, minimum, standard deviations, and range of estimated breeding values (EBV) of productive, reproductive and somatic cell count traits for all animal obtained from multi-trait analysis.

\begin{tabular}{|c|c|c|c|c|c|c|c|c|}
\hline \multicolumn{7}{|c|}{ Multi-trait breeding value } \\
\hline traits & \multicolumn{2}{|c|}{ DO } & \multicolumn{2}{c|}{ TMY } & \multicolumn{2}{c|}{ M1 } & \multicolumn{2}{c|}{ SCC1 } \\
\hline & EBV & S.E & EBV & S.E & EBV & S.E & EBV & S.E \\
\hline Means & 2.0 & 3.28 & 20 & 141 & 13.8 & 11.29 & 1.12 & 448 \\
Max & 117.3 & 42.6 & 5270 & 1830 & 203.2 & 13.86 & 4210 & 4700 \\
Min & -76.6 & 28.3 & -5010 & 1220 & -186 & 9.92 & -2096 & 2380 \\
S.D & 32.7 & 2.6 & 1460 & 0110 & 60.5 & 0.71 & 829 & 230 \\
Range & 193.9 & 70.9 & 10280 & 3050 & 383.8 & 23.78 & 6306 & 7080 \\
\hline
\end{tabular}

In this respect, Togashi et al. (2004) concluded that multiple-trait evaluation appears desirable because it takes into account the genetic and environmental variance-covariance of all traits evaluated. For these reasons, multiple-trait evaluation would reduce bias from selection and achieve a better accuracy of prediction as compared to single-trait evaluation. They add that the number of traits included in multiple-trait evaluation should depend upon the breeding goal. In this respect, Pollak and Quaas (1983) found the same result; they reported that the multiple-trait model is usually preferred over the single-trait model as the former uses the covariance structure among traits and the records with missing information, both of which are ignored by the latter. 


\section{Correlations among EBVs from single traits analyses.}

Correlations among EBVs provided by singe-trait analysis are presented in table ( 6 ). Correlations among EBVs for traits studied of all animals in were positive, except that between DO and each of TMY, DIM , M1 and AFC. The negative estimates were between SCC1 and each of NSC and AFC, also the correlation between NSC and AFC was negative. In general, it could be noticed that the correlations among EBVs provided by single-trait analysis for studied traits were small, indicated that the selection for any trait lead to small change in the other.

Table (6): Correlations coefficients between actual EBVs all animals of the single traits studied.

\begin{tabular}{|l|c|c|c|c|c|c|}
\hline Traits & TMY & DIM & M1 & DO & NSC & AFC \\
\hline DIM & 0.616 & & & & & \\
M1 & 0.327 & 0.082 & & & & \\
DO & -0.205 & -0.178 & -0.016 & & & \\
NSC & 0.061 & 0.049 & -0.021 & 0.246 & & \\
AFC & 0.003 & -0.035 & 0.013 & -0.094 & -0.009 & \\
SCC1 & 0.090 & 0.080 & 0.239 & 0.065 & -0.016 & -0.052 \\
\hline
\end{tabular}

Correlations between EBVs of somatic cell count with milk production were positive and ranged between 0.080 to 0.239 , also, these correlation between somatic cell count and days open were positive $(0.065)$.

Correlation between EBVs from multi-traits analyses.

Correlations between EBVs provided by multi-trait analysis for all animals are presented in table (7). Correlations between EBVs of all animals in pedigree were positive, except that between SCC1 and each of TMY and DO.

Table (7): Correlations coefficients between actual EBVs all animals of the multi-traits studied.

\begin{tabular}{|l|c|c|c|}
\hline Traits & TMY & M1 & DO \\
\hline M1 & 0.271 & & \\
DO & 0.909 & 0.250 & \\
SSC1 & -0.083 & 0.077 & -0.057 \\
\hline
\end{tabular}

Correlations between EBVs of TMY and DO was positive and high (0.909), and also positive correlation between days open and milk yield in the first test of lactation (0.250). The present study indicate that cows with higher milk yield during early lactation and cows with higher genetic merit for milk yield also have longer days open than do cows with mean yield during early lactation (Chauhan et al., 1994). The present findings confirm the antagonistic relationship of milk yield with reproduction under high producing Holsteins under production system of commercial herds.

\section{Conclusions}

The present study indicated that the Holstein dairy farming system in commercial herds in Egypt can show high production performance under 
adequate management. The large coefficients of variation are indicative leaders for opportunities for improvement in these traits. The present results showed some differences in heritabilities obtained from single versus multitrait genetic analyses. Higher standard deviations of breeding value for multitrait than single-trait analyses obtained in the present study indicated the existence of more genetic variation among sires (animals). Also, the sire and cow evaluations for reproduction and somatic cell count in early lactation must be taken into consideration and subsequently incorporated into a multitrait selection index. This will help the farmers to select the best heifers based on a combination of production, reproduction and somatic cell count in early lactation.

\section{REFERENCES}

Abdel-Glil, M.F. (1996). Estimation of genetic parameters and trends for some milk traits in herd of Friesian cows in Egypt. J. Agric. Sci., Mansoura Univ., 29 (10): 5539.

Aboul-Ela, M.B., M.A. Mostafa and N.A. Shalaby (2001). Association between productive and reproductive performance in Holstein Friesian herd in Hungary. J. Agric. Sci., Mansoura Univ., 26 (1): 207.

Alemam, M.A.Z. (2002). Evaluation of reproductive performance of dairy cattle under different production system. M. Sc. Thesis, Fac. Agric., Mansoura Univ., Egypt.

Amin, A.A., S.A. Mokhtar and A.Ghazy (2005). Genetic analysis of the relationship among test-day milk yield, somatic cell count and some udder characteristics of Holstein Friesian cows. Egyptian J. Anim. Prod., 42 (2): 71-85.

Ashmawy, A.A. (1986). Relationship between milk yield in the first lactation, age at first calving and stayability in dairy cattle. Egypt. J. Anim. Prod., 25: 255.

Atil, H. and A.S. Khattab (2005a). Use of multiple traits animal model for genetic evaluation of milk yield and age at first calving of Holstein Friesian cattle in Turky. Pakistan J. Biol. Sci., 8: 114.

Atil, H. and A.S. Khattab (2005b). Estimation of genetic trend for productive and reproductive traits of Holstein Friesian cows in Turky. Pakistan J. Biol. Sci., 8: 202.

Boldman, K. G., L. A. Kriese, L. D. Van Vleck, C. P. Van Tassell, and S. D. Kachman (1995). A manual for use of MTDFREML. USDA, ARS, Clay Center, NE.

Chauhan, V. P. S., J. F. Hayes, and T. Brown (1994). Relationships between days open and milk production traits in Canadian Holsteins. Proc. 5th World Congr. Genet. Appl. Livest. Prod. 17: 109.

Detilleux, J., P. Leroy, and D. Volckaert. (1997). Alternative use of somatic cell counts in genetic selection for mastitis resistance. INTERBULL bulletin no. 15, Uppsala. 34-44.

Dohoo, I.R. and Meek A.H. (1982). Somatic cell counts in bovine milk. Can. Vet. J., 23: 119. 
El-Awady, H.G. (1998). Genetically analysis of reproductive and productive performance of Friesian herds. Ph. D. Thesis, Fac. Agric., Kafr ElSheikh, Tanta Univ., Egypt.

Estrada-Leon, R. J., J.G. Magana and J.C. Segura-Correa (2008). Genetic parameters for reproductive traits of Brown Swiss cows in the Tropics of Mexico. J. animal and Veterinary Advances, 20: 124.

Farrag, F.H.H.; A.S.A. El- Barbary.; M.F. Abdel-Glill and K.Hussein (2000). Studies on Friesian cattle in Egypt. I. Environmental factors affecting milk production. J. Agric. Sci., Mansoura Univ. 25(10):6105.

Gröhn, Y. T., J. A. Hertl and J. L. Harman (1994). Effect of early lactation milk yield on reproductive disorders in dairy cows. Am.J. Vet. Res. 55: 1521.

Hagnestam, C., Emanuelson, U. and B. Berglund (2007). Yield losses associated with clinical mastitis occurring in different weeks of lactation. J. Dairy Sci., 90: 2260.

Harmon, R.J. (1994). Physiology of mastitis and factors affecting somatic cell counts. J. Dairy Sci., 77: 2103-2112.

Hegazy, M.A. and A.H.A Morsy (2005). Evaluation of milk production and its components for Friesian and its crossbred cows under environmental condition in Upper Egypt. J. Appl. Sci., 20(2b):372.

Itavo, L. C.V., G.T. Santos, V.A. Toledo, C.B.F. Ítavo and N.P. Ribas (2001). Milk quality and subclinical mastitis detection through somatic cells counting. Maringá, 23(4): 1065.

Kadarmideen, H. N., R. Thompson, M. P. Coffey, and M. A. Kossaibati (2003). Genetic parameters and evaluations from single- and multipletrait analysis of dairy cow fertility and milk production. J. Livest. Prod. Sci., 81: 183.

Koivula, M., E.A. Mantyssaari, E. Negussie and T. Serenius (2005). Genetic and phenotypic relationships among milk yield and somatic cell count before and after clinical mastitis. J. Dairy Sci., 88: 827.

Li, X., Schutz, M.M., Schinckel, A.P., Lofgren, D.L., (2001). Genetic evaluation of episodes of short and long duration of elevated somatic cell scores. J. Dairy Sci. 84 (Suppl. 1), 248, (Abstract).

Monardes, H.G., and J.F. Hayes (1985). Genetic and phenotypic statistics of lactation cell counts in different lactations of Holstein cows. J. Dairy Sci., 68:1449.

Moore, R.K., B.W. Kennedy, L.R. Schaeffer and J.E. Moxley (1999). Relationships between reproduction traits, age and body weight at calving, days dry in first lactation Ayrshires and Holsteins. J. Dairy Sci., $73: 835$.

Mrode, R.A. and C.J.T. Swanson (2001). Genetic parameters for test-day somatic cell counts for the first three lactations using a random regression model. J. Dairy Sci., 193.

O'Rourke, D.J. (1999). Cell counts and their uses. Cattle Pract., 7: 11.

Oudah, E.Z.M., N.A. Shalaby, and M.A. Mostafa (2001). Genetic and nongenetic factors affecting days open, number of services per conception and age at first calving in a herd of Holstein-Friesian cattle. Pakistan J. Biol. Sci., 4: 740. 
Shalaby, N.A. et al.

Pollak, E.J., and R.L. Quaas (1983). Definition of group effects in sire evaluation models. J. Dairy Sci., 66: 1503.

Pryce, J.E., R.J., Esslemont, R.Thompson, R.F. Veerkamp, M.A. Kossabati and G. Simm, (1998). Estimation of genetic parameters using health. Fertility and production data from a management recording system for dairy cattle. Anim. Sci., 66:577.

Reents, R., J. Jamrozik, L. R. Schaeffer, and J.C.M. Dekkers (1995). Estimation of genetic parameters for test day. J. Dairy Sci., 78:2847.

Rupp, R. and Boichard D. (1999). Genetic parameters for clinical mastitis, somatic cell score, production, udder type traits, and milking ease in first lactation Holsteins. J. Dairy Sci. 82: 2198.

Schaeffer, L. R. (1984). Sire and cow evaluation under multiple trait models. J. Dairy Sci., 67: 1567.

Shalaby, N.A. (2005). Genetic evaluation for total milk production, reproduction traits and persistency of lactation using single-trait animal model analyses for Friesian cows in commercial herds in Egypt. J. Agric. Sci. Mansoura Univ., 30 (7) : 3637.

Tag El-Dein, M.A.(1997). Studies on cattle, phenotypic and genetic parameters of some performance traits in Friesian cattle. Ph.D. Thesis, Fac. of Agric., Alex. Univ., Egypt.

Tag El-Dein, M.A. and K. Hussein (2005). Genetic and phenotypic studies on milk production traits of Friesian in Egypt. J. Agric. Sci., Mansoura Univ., 30 (10): 5849

Togashi, K., C.Y. Lin and K. Yokouchi (2004). Overview of genetic evaluation in dairy cattle. Anim. Sci., J. 75: 275.

Toosi, A. (2002). Genetic and environmental factors affecting some measures of yield and fertility in a registered some measures of yield fertility in a registered Canadian Holstein dairy herd in Iran. Proc. Br. Soc. Anim. Sci., York, (Abstr), PP: 190.

Tsenkova, R., S. Atanassova, S. Kawano, and K. Toyoda (2001). Somatic cell count determination in cows milk by near-infrared spectroscopy: Anew diagnostic tool. J. Anim. Sci., 79: 2550.

Veerkamp, R. F., A.W. Stott, W.G. Hill and S. Brotherstone (1998). The economic value of somatic cell count payment schemes for UK dairy cattle breeding programmes. Anim. Sci., 66: 293.

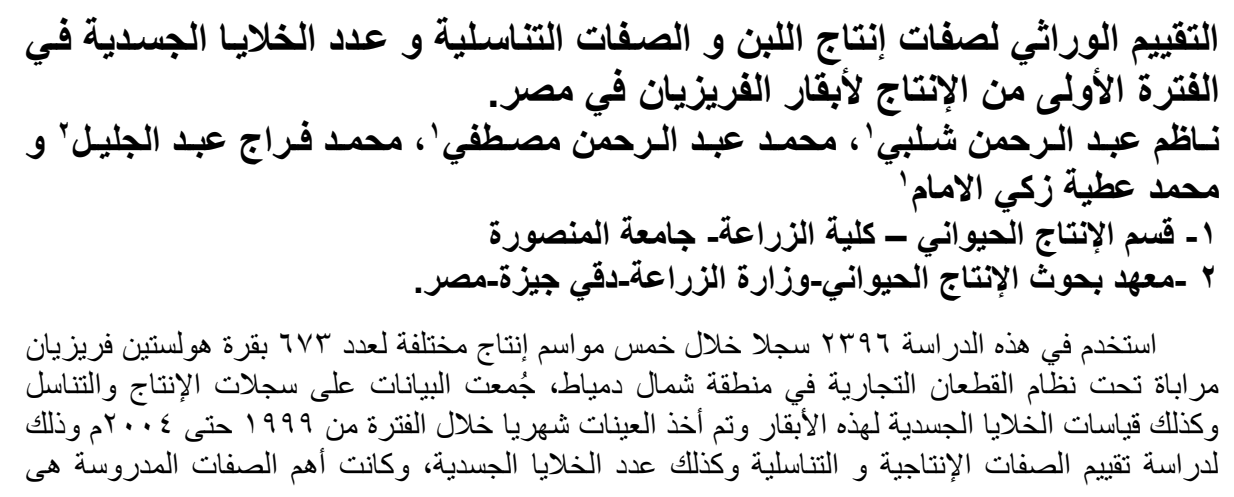




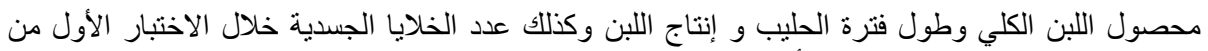

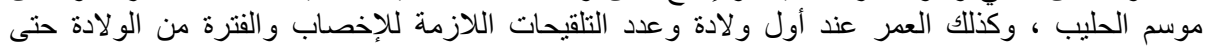

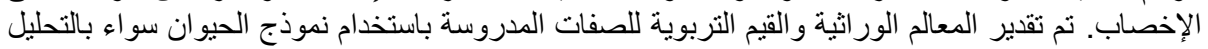

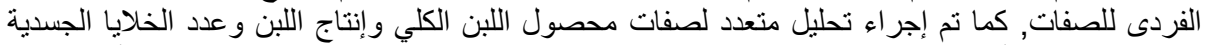

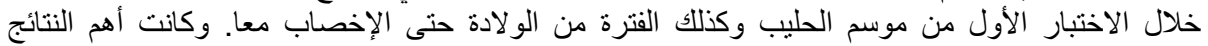

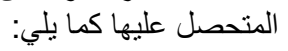

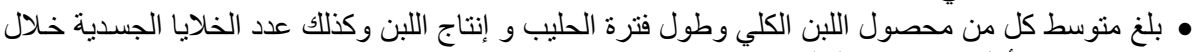

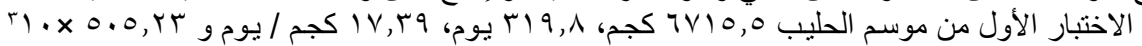

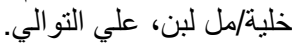

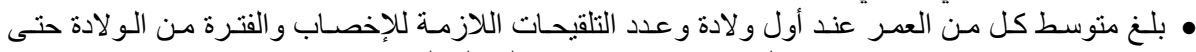

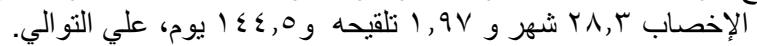

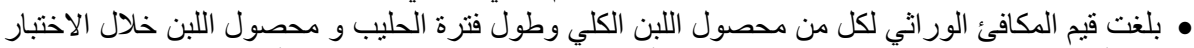

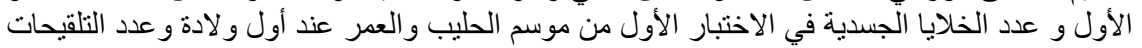

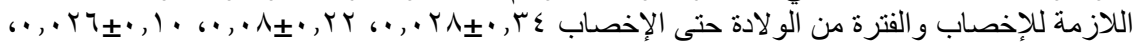

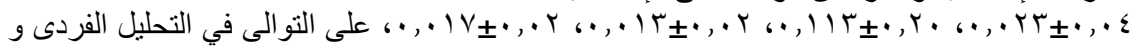

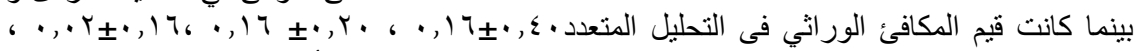

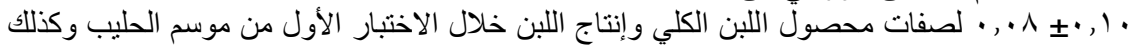

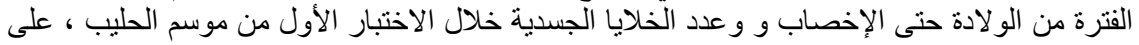

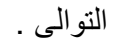

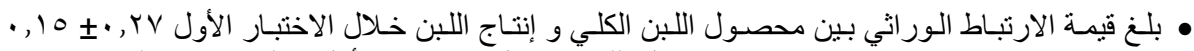

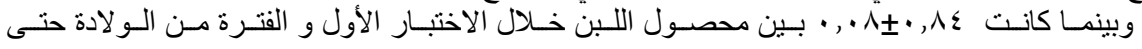
الإخصاب.

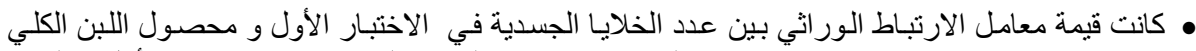

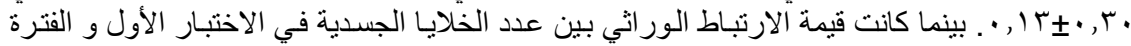

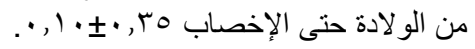

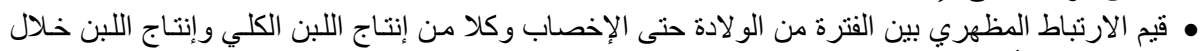

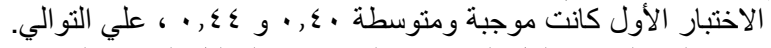

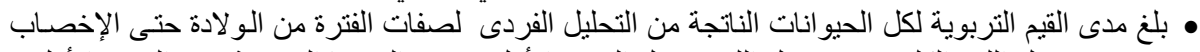

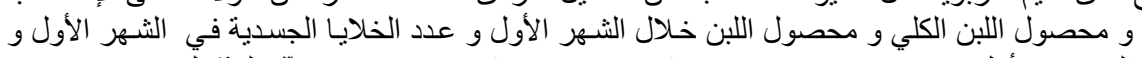

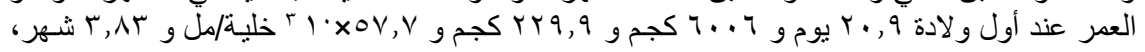

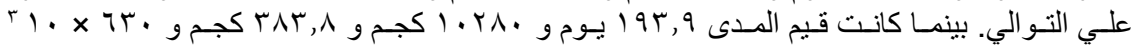

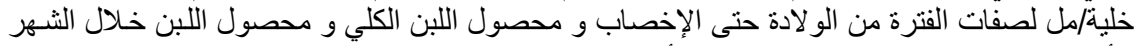

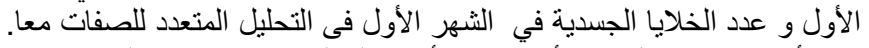

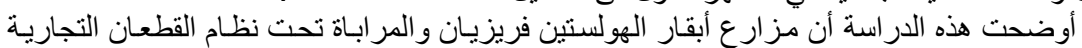

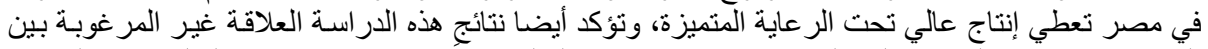

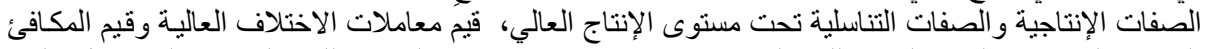

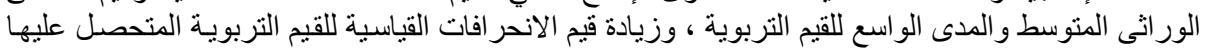

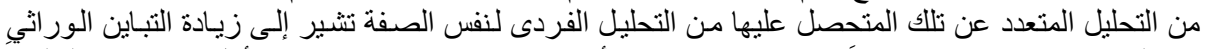

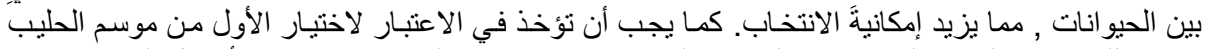

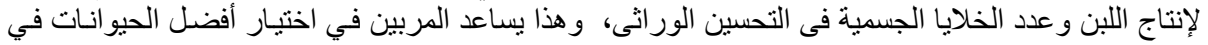

